\title{
Single-Family Room, Neonatal Intensive Care Unit Design
}

\author{
Mahdi Alsaleem* \\ Mahdi Alsaleem MD, Assistant Professor, University of Kansas, USA \\ *Corresponding author: Mahdi Alsaleem MD, Assistant Professor, University of Kansas, USA
}

\begin{tabular}{|c|c|}
\hline ARTICLE INFO & ABSTRACT \\
\hline $\begin{array}{l}\text { Received: 蔧July 25, } 2019 \\
\text { Published: 幽 August 05, } 2019\end{array}$ & $\begin{array}{l}\text { Citation: Mahdi Alsaleem. Single-Family Room, Neonatal Intensive Care Unit Design. Bi- } \\
\text { omed J Sci \& Tech Res 20(2)-2019. BJSTR. MS.ID.003430. }\end{array}$ \\
\hline
\end{tabular}

\section{Introduction}

There has been an increasing trend in adopting the Single-family room (SFR) neonatal intensive care unit (NICU) model in multiple institutions. This rising trend is driven mostly by the positive impact on both short and long term medical and neurodevelopmental outcomes, compared to the open bay unit design. From multiple observations increasing parental involvement seems to be the key factor in improving the different aspects of neonatal outcomes; mainly in the subset of neonates born at less than 30 weeks of gestational age.

\section{Advantages and Disadvantages of the SFR Design}

SFR design provides several benefits in the aspect of neonatal care; including, the neonates, caregivers, and neonatal staff. For the neonates; studies have shown that the SFR design provides more suitable, low noise environment for premature infants during their relatively long period of hospitalization, compared to the open bay design [1]. Also; in the SFR units, it more feasible to control illumination density to provide light levels that can mimic the physiological day/night shifts [1]. Regarding short term adverse outcomes; Stevens D et al. [2] showed in a relatively large sample, that there was no statically significant difference between the infants cared for in both designs including; grade 3 or 4 intraventricular hemorrhage, retinopathy of prematurity, chronic lung disease, or unplanned extubating. Domanico et al. [3] Showed that infants cared for in the SFR unit had decreased incidence of mortality, nosocomial sepsis, and recorded apneic episodes. Another outcome measure they used was breastfeeding succus; which was shown to be more efficient and sustained in the SFR units compared to the open baby design. Comparing the financial aspect, the increased cost of
SFR units can be balanced by the significantly decreased length of stay in SFR units compared to the open bay unit [4]. When the longterm outcomes were evaluated; higher parental involvement observed in the SFR resulted in improved neurobehavioral outcomes at discharge, [5] and both cognitive and language scores at eighteen months of age assessed using Bayley score [6].

Caring for neonates in SFR design improved parents' satisfaction significantly and provided a more convenient model to provide family-centered care and shared decision-making opportunities [7]. In addition to the advantages as mentioned earlier, SFR design resulted in increased staff satisfaction as well as stress level when compared to the open bay model [8]. In spite of these observed advantages; concerns and some reservations exist about the possibility of limited observation of critically ill infants. Concerns also exist about disturbing the teamwork environment by separating the nurses to take care of their closed isolated assigned beds, compared to the open bay unit. The workspace isolation can result in difficulties to provide enough coverage during routine breaks or while transferring neonates for procedures or imaging studies. The use of advanced technological monitoring devices as well as increased the number of staffs can provide potential opportunities to overcome the disadvantages associated with the SFR design [9].

\section{Conclusion}

Multiple positive effects on the neonates, caregivers, and neonatal intensive care unit staff of the single-family room units have been shown from the multiple observations performed in the previous two decades. These effects observed early in life translated to better neurodevelopmental outcomes at later ages. 


\section{Acknowledgment}

None.

\section{Funding Resources and Conflict of Interest}

None.

\section{References}

1. Stevens DC, Helseth CC, Thompson PA, Pottala JV, Khan MA, et al. (2012) A comprehensive comparison of open-bay and single-family-room neonatal intensive care units at Sanford Children's Hospital. HERD: Health Environments Research \& Design Journal 5(4): 23-39.

2. Stevens DC, Munson DP, Khan MA (2016) The single-family room neonatal intensive care environment. Neoreviews 17(12): e687-e696.

3. Domanico R, Davis DK, Coleman F, Davis BO (2011) Documenting the NICU design dilemma: comparative patient progress in open-ward and single-family room units. Journal of Perinatology 31(4): 281-288.

4. Örtenstrand A, Westrup B, Broström EB (2010) The Stockholm Neonata Family Centered Care Study: effects on length of stay and infant morbidity. Pediatrics 125(2): e278-e285.

\section{ISSN: 2574-1241}

DOI: 10.26717/BJSTR.2019.20.003430

Mahdi Alsaleem. Biomed J Sci \& Tech Res

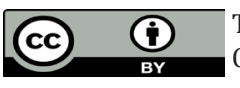

This work is licensed under Creative

Commons Attribution 4.0 License

Submission Link: https://biomedres.us/submit-manuscript.php
5. Lester BM, Hawes K, Abar B (2014) Single-family room care and neurobehavioral and medical outcomes in preterm infants. Pediatrics 134(4): 754-760.

6. Lester BM, Salisbury AL, Hawes K (2016) 18-month follow-up of infants cared for in a single-family room neonatal intensive care unit. The Journal of pediatrics 177: 84-89.

7. Stevens DC, Helseth CC, Khan MA, Munson DP, Reid E (2011) A comparison of parent satisfaction in an open-bay and single-family room neonatal intensive care unit. HERD: Health Environments Research \& Design Journal 4(3): 110-123.

8. Shepley MM, Harris DD, White R (2008) Open-bay and single-family room neonatal intensive care units: caregiver satisfaction and stress. Environment and Behavior 40(2): 249-268.

9. Shahheidari M, Homer C (2012) Impact of the design of neonatal intensive care units on neonates, staff, and families: a systematic literature review. The Journal of perinatal \& neonatal nursing 26(3): 260-266.

BIOMEDICAL
RESEARCHES $\quad \begin{aligned} & \text { Assets of Publishing with us } \\ & \text { - Global archiving of articles }\end{aligned}$

